\title{
HIV and AIDS in Nigeria: Meeting the Rural Challenges
}

\section{Ogboi Sonny Johnbull*}

University of Camerino, Department of Experimental Medicine and Public Health (Malaria \&Human Development), 62032 Camerino (MC), Italy

\begin{abstract}
Human immune deficiency virus (HIV) and acquired immunodeficiency syndrome (AIDS)-HIVIAIDS is a moral and medical problem that require a moral and medical solution without compromising the innocent and without sacrificing our civil liberties at the rural communities in Nigeria. Therefore, everybody (traditional rulers, churches, mosques, schools, farmers etc) have some roles to play which must be unyielding in principle and compassionate in practice that can stem down the spread of HIV at the rural communities.
\end{abstract}

\section{Introduction}

Albert Einstein once said that the unleashed power of the atom had changed everything except our ways of thinking [1]. This same may be true in human relationship after the outbreak of human immune deficiency virus (HIV) and acquired immunodeficiency syndrome (AIDS). We come to terms with radical change only with the greatest reluctance and often too late. If we had started earlier, the cost of prevention will be far less than what we are expending at various levels in various countries. While there are some panics over the new threat to HIV, much current sexual behavior remains unchanged. The moral landscape has in fact altered irrevocably with the onset of HIV/AIDS. Even with the merciful discovery of a cure right now should not be hailed as heralding an automatic return to ways of behaving and moral attitudes dramatically. We need a more fundamental reappraisal.

At the rural level, everybody (traditional rulers, churches, mosques, schools, farmers etc) have some roles to play which must be unyielding in principle and compassionate in practice $[2,3]$.

The communities must clearly condemn immorality but never disown the one that committed such act because it would be quite clear that there are sufferers who have contacted the illness through no fault of their own. But confronted with the complexity of this epidemic, we are going to do well to remember that all is by no means lost. It is still possible for the policy makers to draw back from the brink and to lessen, if not entirely eliminate the menace of the HIV and AIDS epidemic and indeed learn from it.

At this juncture, we desperately need the knowledge, skills and inventiveness of scientist, doctors and other health personnel. Now, we have to learn how to live and love in a more genuinely way.

In rural community across Nigeria, we cannot yet guess at the magnitude of HIV and AIDS which confronts us but our response will have to be specific, swift, imaginative and radical. The compassion and care for those who are infected, sick and for their families must go paripassu with a vigorous and uncompromising campaign to educate those at risk because of the dangers of sexual irresponsibility.

As I write this article more and more people are being infected daily by HIV infection and are migrating to rural communities once diagnosed and confirmed. And the worries about this HIV/AIDS are so many at the rural communities; what do we as individuals need to know about HIV/AIDS? How does it affect us personally? How does our behavior influence what we think? What are we saying about HIV/ AIDS? What shall we do? What can we do? This has challenge our moral integrity, our educational systems, our care to the sick and the dying and our expectations at the community level because hardly a day goes by on our nation without a mention of HIV/AIDS in the national dailies and the government spending millions of naira (dollars) on advertising and information campaign.

HIV/AIDS has called all activities into being and challenges them to ensure that they are not just a routine, not adequate but that they can meet the challenge since it is presenting us with a sudden crisis which demands a quick response. One question that remains difficult to answer is, how we alter the expectations and attitudes of young people at the rural communities of our country towards sexuality with different cultural beliefs.

Past and present experiences proclaim loudly that a rigid and onesided emphasis on sexual morality is counter-productive and causes dangerous reactions. Sexual morality is of paramount importance, but education for sexual morality responsibility can operate only if people understand deeply their responsibility for their own wellbeing. HIV/AIDS require us to become responsible persons from responsible communities, and societies, and concentrate on education for responsibility. Yet it is not possible to sharpen people's conscience for responsibility on this point, HIV/AIDS, unless we educate ourselves and help others to develop an overall sense of responsibility for our own health, for the health of others, for healthy human relationships, and for peace and justice.

In rural communities, HIV spread is increasing. It is a hard saying but nonetheless true that our future as a community or society depends on our rediscovery of a strict moral code.

Being HIV positive has ruined so many homes and lives. It has brought relationships and marriages to an abrupt end, leaving hearts broken and souls shattered. Being an incurable ailment that ends in catastrophe, except dictated early, people find it difficult to associate or have something in common with people infected with this disease let alone making love to them.

*Corresponding author: Ogboi Sonny Johnbull, University of Camerino, Department of Experimental Medicine and Public Health (Malaria \&Human Development), 62032 Camerino (MC), Italy, E-mail: ogboijb@yahoo.com

Received December 14, 2012; Accepted December 26, 2012; Published December 28, 2012

Citation: Johnbull OS (2013) HIV and AIDS in Nigeria: Meeting the Rural Challenges. J AIDS Clin Res 4: e111. doi:10.4172/2155-6113.1000e111

Copyright: (c) 2013 Johnbull OS, et al. This is an open-access article distributed under the terms of the Creative Commons Attribution License, which permits unrestricted use, distribution, and reproduction in any medium, provided the original author and source are credited. 
We need urgently to live by values which accept that sexual love in its fullness is to express only within lifelong and faithful marriage. Only in this way can we safeguard and develop what is noblest and best in human nature.

One of the most pressing needs for those who have HIV/AIDS in our rural communities is accommodation because once a person is diagnosed as HIV positive they face the pressure either from those they live with or landlords to move out. They need safe accommodation where they can carry on positive living without undue attention and harassment.

In conclusion, AIDS is special and different because it has presented us with a sudden crisis which demands a response. HIV/AIDS is a moral and medical problem and we should go for a moral medical solution without compromising the innocent and without sacrificing our civil liberties at the rural communities in Nigeria.

\section{References}

1. http://www.chacha.com/question/what-did-albert-einstein-warn-us-abouttechnology

2. Federal Ministry of Health (2005) The 2007 National AIDS and Reproductive Health Survey (NARHS). Abuja, Nigeria.

3. Federal Ministry of Health, National AIDS/STD Control Program (NASCP) (1999) A Report of 1995/96 HIV Sentinel Sero-Surveillance in Nigeria. Abuja, Nigeria. 